\title{
Response of peach nursery plants to different doses of nitrogen and plant densities
}

Shahid Jamal ${ }^{1}$, Jawad Ali shah ${ }^{1 *}$, Jawad Ali $^{1}$, Muhammad Ismaeel ${ }^{2}$, Zakria Bacha ${ }^{3}$, Amin $\mathrm{Khan}^{3}$ and Ijaz Naeem ${ }^{4}$

1. Department of Agriculture,University of Swabi,Anbar,Swabi-Pakistan

2. Agricultural Research Station Swabi,KP-Pakistan

3. Agricultural Research Institute (north) Mingora Swat-Pakistan

4. Institute of Biotechnology and Genetic Engineering, The university of Agricultue Peshawar-Pakistan

*Corresponding author's email: jawadalishah@uos.edu.pk

Citation

Shahid Jamal, Jawad Ali shah, Jawad Ali, Muhammad Ismaeel, Zakria Bacha, Amin Khan and Ijaz Naeem.

Response of peach nursery plants to different doses of nitrogen and plant densities. Pure and Applied Biology. Vol. 6, Issue 2, pp544-552. http://dx.doi.org/10.19045/bspab.2017.60056

\begin{tabular}{llll}
\hline \hline Received: 30/12/2016 & Revised: 26/03/2017 & Accepted: 08/04/2017 & Online First: 15/04/2017 \\
\hline
\end{tabular}

\section{Abstract}

A field experiment was carried out at the Agriculture Research Institute Tarnab during the year. The response of peach nursery plants to different doses of nitrogen and plant densities was studied. Three levels of nitrogen, 0,57 and $114 \mathrm{~kg} /$ hectare were used along with four different planting densities i.e. 536, 804, 1005 and 1072 seedlings per plot. It was found that seedling height $(\mathrm{cm})$, diameter $(\mathrm{mm})$, bud take success $(\%)$, scion length $(\mathrm{cm})$ and root volume $\left(\mathrm{cm}^{3}\right)$ were significantly affected by different levels of nitrogen and planting densities, whereas time taken to reach buddable size was not affected in any treatment. Maximum seedling height, diameter, bud take success, scion length and root volume were $94.34 \mathrm{~cm}, 7.17 \mathrm{~mm}, 82.43 \%, 181.25 \mathrm{~cm}$ and $667 \mathrm{~cm}^{3}$ respectively for the maximum nitrogen dose of $114 \mathrm{~kg} \mathrm{ha}^{-1}$. For different plant densities, the maximum seedling height, diameter, bud take success, scion length and root volume were $94.12 \mathrm{~cm}, 7.16 \mathrm{~mm}, 79.85 \%, 178.34 \mathrm{~cm}$, and $672 \mathrm{~cm}^{3}$ respectively, for plots having 506 plants. Though, statistically the seedling height $(98.51 \mathrm{~cm})$, seedling diameter $(8.17 \mathrm{~mm})$, scion length $(187.25 \mathrm{~cm})$ and root volume $\left(783 \mathrm{~cm}^{3}\right)$ were highest for interaction, in plots with $114 \mathrm{~kg}$ nitrogen ha $\mathrm{h}^{-1}$ and 536 seedlings. But the seedling height $(95.24 \mathrm{~cm})$, seedling diameter $(7.12$ $\mathrm{mm})$, scion length $(182.71 \mathrm{~cm})$ and root volume $\left(746 \mathrm{~cm}^{3}\right)$ in the plots receiving the similar nitrogen dose having plant density of 804 were found to be comparably more economical. Thus, from our findings we recommend a plant density of 85760 and a nitrogen dose of $114 \mathrm{~kg}$ per hectare.

Keywords: Peach (Prunus persica L.); Nitrogen; Seedling height; Seedling diameter; Root volume

\section{Introduction}

Peach (Prunus persica L.) belongs to the family Rosaceae and is a main stone fruit of the temperate zone. The cultivation history goes back to 2000 B.C. It originated in China as a wild form. It is evident from the literature that the Romans cultivated peach about the time of Christ and extended its 
cultivation to all over their empire in Europe. Peach is now distributed all over the world and it is an essential commercial and home garden stone fruit all over the temperate regions of the world [1].

Peach can be consumed as fresh or canned, dried, frozen and preserved as jams and jellies. Fresh peaches are available in the local market from late spring to early autumn. The agro-climatic conditions of the Khyber Pakhtunkhwa are best suited for the cultivation of peach and are grown on more than 5700 hectares producing 53100 tons of fruit in the province. Peach is the second most important and popular stone fruit (after plum) in Pakistan. It is grown on 15400 ha area with production over 71200 tonnes. [2] Peaches can grow on a wide range of soils, depending upon the root stock, but best results can be achieved if grown on rich, well drained, loamy soils with deep subsoil. Peaches grow best and produce maximum fruits on a deep, reasonably fertile, well drained sandy loam soil [3]. Generally peaches require high nitrogen fertilizer. It is an established fact that plant vigour increases with the application of nitrogenous fertilizers various sources of nitrogen release nitrogen in different ways and thus acts differently. Also, in different soils the various nitrogen sources produce different results. This experiment was designed to evaluate the response of local peach seedlings to nitrogen levels and planting densities [3].

It is worth to mention that no proper recommendation exists for its dose in stone nursery in soil and climatic conditions of Peshawar. So this study will enable the nursery grower to have a proper dose recommendation of nitrogen fertilizer as well as the newly introduced sowing techniques. Considering the row spacing, the nursery growers of Khyber Pakhtunkhwa traditionally keep $70-75 \mathrm{~cm}$ row to row spacing. The plants per unit area can be increased, in turn yielding more plants per unit area. This study will enable us to:

1. Increase the production of nursery plant per unit area.

2. Allocate an appropriate dose of nitrogen fertilizer for stone fruit nursery.

3. Determine the optimum row spacing for stone fruit nursery.

4. Increase the income of nursery growers.

\section{Materials and methods}

The experiment to study the was carried out at Agricultural Research Institute Tarnab Peshawar during the year 2008-2009 using randomized complete block design with split plot arrangement replicated three times. Sowing was done in the last week of November, 2008 and germinated in March, 2009. Urea was used as nitrogen source applied to the nursery plants in the last week of May, 2009. After the plants achieved a diameter of a pencil, they were budded with peach variety, early grand (24 June, 2009). Root volume was recorded after rooting up of the nursery plants in December, 2009.

The description of factors is given as follows

\section{Main plot}

Nitrogen dose having three different levels.

\begin{tabular}{|l|l|}
\hline Rate & Actual quantity \\
\hline Control plots & Nitrogen $0 \mathrm{~g} 31.60 \mathrm{~m}^{2}$ \\
\hline Nitrogen $57 \mathrm{~kg} \mathrm{ha}^{-1}$ & Nitrogen $50.6 \mathrm{~g} 31.60 \mathrm{~m}^{2}$ \\
\hline Nitrogen $114 \mathrm{~kg} \mathrm{ha}^{-1}$ & Nitrogen $101.2 \mathrm{~g} 31.60 \mathrm{~m}^{2}$ \\
\hline
\end{tabular}

\section{Sub plot}

Plant population per $31.60 \mathrm{~m}^{2}$ having four treatments.
1. 536 plants
2. 804 plants
3. 1005 plants
4. 1072 plants

\section{Parameters studied were as under Seedling height $(\mathrm{cm})$}

The height of ten seedlings was measured randomly in each plot with the help of measuring tape, and averages were calculated. 


\section{Seedling diameter $(\mathbf{m m})$}

The diameter of ten seedlings was recorded randomly in each plot with the help of vernier calliper. The seedling diameter was recorded six inches above the ground level.

\section{Time from sowing to budding}

The duration from sowing date to budding stage was recorded in days.

\section{Bud take success percent}

The bud take success percentage was calculated by recording the number of successful buddlings, the following formula was used,

Bud take success percent $=$ No. of successful budded plants $\times 100$

\section{Buddling height (cm)}

Total No. of budded plants

Buddling height was recorded in centimetres, from the base of the scion up to its shoot apex, and averages of the ten random samples from each plot were calculated.

\section{Root volume (ml)}

Root volume of ten randomly selected samples from each plot was measured with the help of a calibrated cylinder. Root volume was taken in cubic centimetres. Increase in volume of water in calibrated cylinder was recorded, when the roots were dipped in the cylinder. The roots were submerged up to the crown.

\section{Results and discussion}

The results of the experiment are discussed as under;

\section{Seedling height $(\mathrm{cm})$}

The data recorded for seedling height are presented in Table 1. The analysis of variance revealed that the nitrogen doses $(\mathrm{N})$ and plant density (T) as well as their interaction had highly significant effects on the seedling height. Comparison of means for different nitrogen doses showed that maximum seedling height $(94.34 \mathrm{~cm})$ was recorded in plots receiving $114 \mathrm{~kg}$ nitrogen $\mathrm{ha}^{-1}$. The minimum seedling height $(85.12$ $\mathrm{cm})$ was recorded in control plots $\left(0 \mathrm{~kg} \mathrm{n} \mathrm{ha}{ }^{-}\right.$ $\left.{ }^{1}\right)$. The different plant densities also affected the seedling height significantly and maximum height of $94.12 \mathrm{~cm}$ was found in plots having 536 plants (8 rows plot $^{-1}$ ) followed by $90.61 \mathrm{~cm}$ in plots having 804 plants (12 rows plot $^{-1}$ ) while the minimum height $(86.71 \mathrm{~cm})$ was recorded plots having 1072 plants (16 rows plot $\left.^{-1}\right)$. The interaction effect was also highly significant as the data revealed that the maximum height $(98.51 \mathrm{~cm})$ was observed in plots receiving $114 \mathrm{~kg}$ nitrogen $\mathrm{ha}^{-1}$ with 536 plant density (8 rows plot $^{-1}$ ) followed by $96.10 \mathrm{~cm}$ height in plots receiving $57 \mathrm{~kg}$ nitrogen $\mathrm{ha}^{-1}$ having 536 plants density. The plant height $(95.24 \mathrm{~cm})$ in plots receiving $114 \mathrm{~kg}$ nitrogen $\mathrm{ha}^{-1}$ with 804 plants density is on third position which is comparable to 98.51. The minimum height $(83.49 \mathrm{~cm})$ was recorded in control plots $\left(\mathrm{N}=0 \mathrm{~kg} \mathrm{ha}^{-1}\right.$ ) having 1072 plants (16 rows plot $\left.^{-1}\right)$. Though statistically the plant height $(98.51 \mathrm{~cm})$ is highest for $114 \mathrm{~kg}$ nitrogen in plots with 536 seedlings but the plant height of $95.24 \mathrm{~cm}$ in plots receiving similar nitrogen dose in plant density of 804 seems more economical. Thus at the cost of only $3.27 \mathrm{~cm}$ we get 804 plants instead of 536 . These finding are clearly serving the objectives of the experiment, the findings are also in agreement with [2] carried out a study at Citrus Research Station, Sargodha, during 2002-2004 on three planting densities of grape fruit. They reported that plant height was positively correlated with planting distance, whereas plant spread did not respond at all. 
Table 1. Effect of different nitrogen doses and plant densities on seedling height $(\mathrm{cm})$ of peach

\begin{tabular}{|l|c|c|c|c|}
\hline \multirow{2}{*}{$\begin{array}{l}\text { Plant density } \\
\text { (No. of plants per } \mathbf{3 1 . 6 0} \mathbf{~ m}^{2} \text { ) }\end{array}$} & \multicolumn{3}{|c|}{ Nitrogen Levels $\left(\mathbf{k g ~ h a}^{-\mathbf{1}}\right)$} & \multirow{2}{*}{ Mean } \\
\cline { 2 - 4 } & $\mathbf{0}$ & $\mathbf{5 7}$ & $\mathbf{1 1 4}$ & \\
\hline 536 & $87.73 \mathrm{~g}$ & $96.10 \mathrm{~b}$ & $98.51 \mathrm{a}$ & $94.12 \mathrm{a}$ \\
\hline 804 & $85.18 \mathrm{~h}$ & $91.42 \mathrm{e}$ & $95.24 \mathrm{c}$ & $90.61 \mathrm{~b}$ \\
\hline 1005 & $84.10 \mathrm{i}$ & $88.84 \mathrm{f}$ & $92.78 \mathrm{~d}$ & $88.57 \mathrm{c}$ \\
\hline 1072 & $83.49 \mathrm{j}$ & $85.84 \mathrm{~h}$ & $90.81 \mathrm{e}$ & $86.71 \mathrm{~d}$ \\
\hline Mean & $85.12 \mathrm{c}$ & $90.55 \mathrm{~b}$ & $94.34 \mathrm{a}$ & \\
\hline
\end{tabular}

LSD for Nitrogen $=0.5292$, LSD for Plant density $=0.3899$, LSD for $\mathrm{N} \times \mathrm{R}=0.6754$

\section{Seedling diameter $(\mathrm{mm})$}

The data pertaining to seedling diameters are presented in Table 2. The analysis of variance revealed that the Nitrogen levels and different plant densities are significantly different regarding the diameter of the seedling. The interaction of both nitrogen and plant density had also significant effect on seedling diameter. The comparison of means for seedling diameter showed that maximum diameter of $7.17 \mathrm{~mm}$ was recorded in plots receiving $114 \mathrm{~kg}$ nitrogen $\mathrm{ha}^{-1}$ followed by $6.57 \mathrm{~mm}$ in plots receiving $57 \mathrm{~kg}$ nitrogen $\mathrm{ha}^{-1}$, the minimum being 5.44 $\mathrm{mm}$ in control plots $\left(0 \mathrm{~kg}\right.$ nitrogen $\left.\mathrm{ha}^{-1}\right)$. This suggests that nitrogen plays an important role in enhancing the vegetative growth of plants. The different plant densities (treatments) also affected the seedling diameter significantly. The maximum diameter $7.16 \mathrm{~mm}$ was recorded in plots having 536 plants $\left(8\right.$ rows plot $^{-1}$ ) followed by $6.52 \mathrm{~mm}$ in plots having 804 plants $\left(12\right.$ rows plot $\left.^{-1}\right)$. The lowest diameter $(5.84 \mathrm{~mm})$ was recorded in plots having 1072 plants (16 rows plot $\left.^{-1}\right)$. Hence, indicating the adverse effect of competition among plants for nutrients, light and water, necessary for vital and optimum growth of the plants. The interaction effect was also significant for seedling diameter. The maximum diameter $(8.17 \mathrm{~mm})$ was recorded in plots receiving $114 \mathrm{~kg}$ nitrogen ha $^{-1}$ with 536 plants $\left(8\right.$ rows plot $\left.{ }^{-1}\right)$, followed by $(7.13 \mathrm{~mm})$ in plots receiving $57 \mathrm{~kg}$ nitrogen ha ${ }^{-1}$ with 536 plants $\left(8\right.$ rows plot $\left.{ }^{-1}\right)$, while $(7.12 \mathrm{~mm})$ in the plots receiving 114 $\mathrm{kg}$ nitrogen ha- ${ }^{-1}$ having 804 plants. The minimum being $4.80 \mathrm{~mm}$ observed in control plots having 1072 plants. It is evident from the table that the trunk cross sectional area (TCA) or diameter was maximum and minimum for plots receiving $114 \mathrm{~kg}$ nitrogen $\mathrm{ha}^{-1}$ and control plots respectively. This clearly suggests the importance of nitrogen as a structural component of plant body and that the combination of both nitrogen and optimum density have good effect on the diameter of young peach seedlings. The vegetative attributes of the plant growth need mineral nitrogen and ample soil volume hence, aerial space for their optimum growth. However, regarding the objectives of the experiment, though the seedling diameter $(8.17 \mathrm{~mm})$ is highest for $114 \mathrm{~kg}$ nitrogen in plots with 536 seedlings but the seedling diameter (7.12 $\mathrm{mm}$ ) in plots receiving similar nitrogen dose in plant density of 804 . The seedling diameter, $7.12 \mathrm{~mm}$ is comparable with the highest measurement of $8.17 \mathrm{~mm}$. But the number of plants is more; with a difference of only $1.05 \mathrm{~mm}$ we get 804 plants instead of 536. These facts discussed above are in agreement with [4] who reported an increase of $48.8 \%$ and $41.7 \%$ in trunk diameter of young peach replants with nitrate of a soda and "pa-pid- 620" respectively. In control replants diameter was $13.3 \%$, while chlorophyll contents of the leaves in control were about half those of fertilized trees. [5] also from their study on peach have reported 
that the trunk cross sectional area (TCA) increased with aerial spacing every year but TCA increased with rooting volume in only the $2.0 \mathrm{~m}$ spacing during the first year. Shoot length increased with increasing spacing in 3 out of 4 years.

Table 2. Effect of different nitrogen doses and plant densities on seedling diameter (mm) of peach

\begin{tabular}{|c|c|c|c|c|}
\hline \multirow{2}{*}{$\begin{array}{l}\text { Plant density } \\
\left(\text { No. of plants per } 31.60 \mathrm{~m}^{2}\right)\end{array}$} & \multicolumn{3}{|c|}{ Nitrogen Levels $\left(\mathrm{kg} \mathrm{ha}^{-1}\right)$} & \multirow[t]{2}{*}{ Mean } \\
\hline & $\mathbf{0}$ & 57 & 114 & \\
\hline 536 & $6.19 \mathrm{e}$ & $7.13 \mathrm{~b}$ & $8.17 \mathrm{a}$ & $7.16 \mathrm{a}$ \\
\hline 804 & $5.70 \mathrm{f}$ & $6.75 \mathrm{~cd}$ & $7.12 \mathrm{bc}$ & $6.52 \mathrm{~b}$ \\
\hline 1005 & $5.08 \mathrm{~g}$ & $6.30 \mathrm{e}$ & $6.80 \mathrm{~cd}$ & $6.06 \mathrm{c}$ \\
\hline 1072 & $4.80 \mathrm{~g}$ & $6.10 \mathrm{e}$ & $6.60 \mathrm{~d}$ & $5.84 \mathrm{~d}$ \\
\hline Mean & $5.44 \mathrm{c}$ & $6.57 \mathrm{~b}$ & $7.17 \mathrm{a}$ & \\
\hline
\end{tabular}

LSD for Nitrogen $=0.1014$, LSD for Plant density $=0.1744$, LSD for $\mathrm{N} \times \mathrm{R}=0.3020$

\section{Bud take success (\%)}

The data pertaining to bud take success for the peach seeding are presented in Table 3. The analysis of variance for bud take success reflected the fact that nitrogen as well as plant densities had significant effect on bud take success percentage but the effect of interaction is non-significant.

Comparing the mean values for different nitrogen doses revealed that the maximum bud take success $(82.43 \%)$ was recorded in plots receiving $114 \mathrm{~kg}$ nitrogen $\mathrm{ha}^{-1}$ followed by $(79.72 \%)$ in plots receiving 57 $\mathrm{kg}$ nitrogen $\mathrm{ha}^{-1}$. The minimum $(75.53 \%)$ was found for control plots. Different plant densities also had significant effect on bud take success. Maximum bud take success $(79.85 \%)$ was found in plots having 536 plants (8 rows plot $\left.^{-1}\right)$ followed by $(79.58 \%)$ in plots having 804 plants (12 rows plot $\left.^{-1}\right)$, while the minimum $(78.34 \%)$ in plots having 1072 plants (16 rows plot $\left.^{-1}\right)$, however, interactions were no significant.

Though, the bud take success percentage is the same for $114 \mathrm{~kg}$ nitrogen in plots with 536 plants and in plots receiving similar nitrogen dose with 804 plants. But the later seems more economical, as we get 804 plants instead of 536 .

The data clearly show that the nitrogen is the responsible factor for bud take success percentage. As all the vegetative attributes are enhanced by the nitrogen application but the bud take success also depends on the callus formation in both stock and scion. Whereas the density also affects it significantly, as the budder has the ease to work in less dense plantation. The above results are in accordance with [6] who studied the effect of different levels of nitrogen using two different sources i.e. urea and ammonium nitrate, on height, diameter, bud success and buddling height at Malakandher Farm, Khyber Pakhtunkhwa Agricultural University Peshawar. Besides control, nitrogen levels of 60, 90, 120 and 150 $\mathrm{kg}$ nitrogen $\mathrm{ha}^{-1}$ were used. Different doses of nitrogen from urea and ammonium nitrate significantly enhanced seedling height and girth. Minimum seedling height and diameter were recorded in control plots. Ammonium nitrate significantly increased bud success and plant height after budding. Nitrogen at 60 and $120 \mathrm{~kg} \mathrm{ha}^{-1}$ significantly increased bud take success, while $60 \mathrm{~kg}$ nitrogen $\mathrm{ha}^{-1}$ yielded significant increase in height of the budded plants when ammonium nitrate was used as a source of nitrogen. Urea was not as effective as ammonium nitrate. 
Table 3. Effect of different nitrogen doses and plant densities on bud take success (\%) of peach seedling

\begin{tabular}{|l|c|c|c|c|}
\hline \multirow{2}{*}{$\begin{array}{l}\text { Plant density } \\
\left(\text { No. of plants per } \mathbf{3 1 . 6 0} \mathbf{~ m}^{2}\right)\end{array}$} & $\mathbf{3}$ & Nitrogen Levels $\left(\mathbf{k g ~ h a}^{\mathbf{- 1}}\right)$ & \multirow{2}{*}{ Mean } \\
\cline { 2 - 4 } & 76.20 & $\mathbf{5 7}$ & $\mathbf{1 1 4}$ & \\
\hline 536 & 75.74 & 80.46 & 82.90 & $79.85 \mathrm{a}$ \\
\hline 804 & 75.28 & 79.63 & 82.90 & $79.58 \mathrm{a}$ \\
\hline 1005 & 74.90 & 78.66 & 81.51 & $79.14 \mathrm{~b}$ \\
\hline 1072 & $75.53 \mathrm{c}$ & $79.72 \mathrm{~b}$ & $82.43 \mathrm{a}$ & $78.34 \mathrm{c}$ \\
\hline Mean & \multicolumn{2}{|l}{} \\
\hline
\end{tabular}

LSD for Nitrogen $=2.524$, LSD for Plant density $=0.33$, LSD for N x R $=$ N.S

\section{Buddling height (cm)}

The data related to buddling height are presented in Table 4 . The statistical analysis showed that nitrogen and plant densities have significant effect on buddling height, the interactions were also significant. Comparison of means for different doses of nitrogen revealed that the maximum buddling height $(181.25 \mathrm{~cm})$ was recorded in plots receiving $114 \mathrm{~kg}$ nitrogen $\mathrm{ha}^{-1}$ which was followed by $(176.94 \mathrm{~cm})$ in plots receiving $57 \mathrm{~kg}$ nitrogen $\mathrm{ha}^{-1}$. The minimum was $159.87 \mathrm{~cm}$ in control plots. On the other hand the values for different plant densities suggest that there is significant effect of density on buddling height. The maximum value of $178.34 \mathrm{~cm}$ was recorded in plots with 536 plants $\left(8\right.$ rows plot $\left.^{-1}\right)$ followed by 173.51 $\mathrm{cm}$ in plots having 804 plants (12 rows plot ${ }^{-1}$ ), while the minimum was $164.74 \mathrm{~cm}$ in plots having 1072 plants $\left(16\right.$ rows plot $\left.^{-1}\right)$. The interaction effect was also found to be significantly affecting the buddling height. The buddling height $(187.25 \mathrm{~cm})$ is highest for $114 \mathrm{~kg}$ nitrogen $\mathrm{ha}^{-1}$ in plots with 536 plants is followed by $(183.85 \mathrm{~cm})$ for $57 \mathrm{~kg}$ nitrogen ha $^{-1}$ in plots with 536 plants but the buddling height of $182.71 \mathrm{~cm}$ in plots receiving $114 \mathrm{~kg}$ nitrogen $\mathrm{ha}^{-1}$ with 804 plants is also comparable to the height of plants having the highest measurement, with the meagre difference of $4.54 \mathrm{~cm}$ in plots with 804 plants. This clearly serves the objectives of this experiment. The minimum buddling height $(156.63 \mathrm{~cm})$ was recorded in control plots. The growth rate or plant height is positively co-related with nitrogen fertilizer available to the plant along with other nutrients. The effect of nitrogen fertilizer was more evident than the effect of planting density on vertical growth of the buddlings. The density also effects the vertical growth of the buddling but the variation is less as compared the effect of nitrogen. This may be due to the tendency of the plants to gain height in order to compete for light. According to [7] increasing the nitrogen levels in Elberta peach increased vegetative growth in some ways. The effectiveness of plants in absorbing and utilizing the available potassium and manganese as compared to control treatment increased with increase in nitrogen level. He also reported favourable effect on foliage with increased application of nitrogen. 
Table 4. Effect of different nitrogen doses and plant densities on buddling height $(\mathrm{cm})$ of peach seedling

\begin{tabular}{|c|c|c|c|c|}
\hline \multirow{2}{*}{$\begin{array}{l}\text { Plant density } \\
\left(\text { No. of plants per } 31.60 \mathrm{~m}^{2}\right)\end{array}$} & \multicolumn{3}{|c|}{ Nitrogen Levels $\left(\mathrm{kg} \mathrm{ha}^{-1}\right)$} & \multirow[t]{2}{*}{ Mean } \\
\hline & $\mathbf{0}$ & 57 & 114 & \\
\hline 536 & $163.93 \mathrm{~g}$ & $183.85 \mathrm{~b}$ & $187.25 \mathrm{a}$ & $178.34 \mathrm{a}$ \\
\hline 804 & $161.38 \mathrm{~h}$ & $176.42 \mathrm{e}$ & $182.71 \mathrm{c}$ & $173.51 \mathrm{~b}$ \\
\hline 1005 & $157.54 \mathrm{i}$ & $170.06 \mathrm{f}$ & $178.88 \mathrm{~d}$ & $168.83 \mathrm{c}$ \\
\hline 1072 & $156.63 \mathrm{j}$ & $161.42 \mathrm{~h}$ & $176.15 \mathrm{e}$ & $164.74 \mathrm{~d}$ \\
\hline Mean & $159.87 \mathrm{c}$ & $172.94 \mathrm{~b}$ & $181.25 \mathrm{a}$ & \\
\hline
\end{tabular}

LSD for Nitrogen $=1.011$, LSD for Plant density $=0.3344$, LSD for $\mathrm{N} \times \mathrm{R}=0.5792$

\section{Root volume $\left(\mathrm{cm}^{3}\right)$}

The data regarding the root volume measured at the end of the experiment are presented in Table 5.

The analysis of variance (ANOVA) revealed that both nitrogen and plant density along with their interaction had significantly affected the root volume. Comparing the means for nitrogen levels showed that the maximum root volume $\left(667 \mathrm{~cm}^{3}\right)$ was found in plots receiving $114 \mathrm{~kg}$ nitrogen $\mathrm{ha}^{-1}$, followed by $577 \mathrm{~cm}^{3}$ in plots receiving 57 $\mathrm{kg}$ nitrogen $\mathrm{ha}^{-1}$ and $445 \mathrm{~cm}^{3}$ in control plots. The means for plant densities suggests that the maximum root volume $\left(672 \mathrm{~cm}^{3}\right)$ was found in plots having 536 plants (8 rows plot $^{-1}$ ), followed by $590 \mathrm{~cm}^{3}$ in plots having 804 plants (12 rows plot $\left.^{-1}\right)$. The minimum root volume $\left(473 \mathrm{~cm}^{3}\right)$ was recorded in plots having 1072 plants (highly dense pattern).

The data for interaction showed that though statistically the maximum root volume $\left(783 \mathrm{~cm}^{3}\right)$ is highest for $114 \mathrm{~kg}$ nitrogen in plots with 536 seedlings but the root volume $\left(746 \mathrm{~cm}^{3}\right)$ in plots receiving similar nitrogen dose with plant density of 804 seems more economical. Thus at the cost of only $37 \mathrm{~cm}^{3}$ we get 804 plants instead of 536. While the minimum value for interaction was $418 \mathrm{~cm}^{3}$ for control plots with 1072 plants. From the data recorded for root volume we can easily assume that the roots are the most affected by competition, in case of peach seedlings. Further during measurement of root volume it was observed that the number of feeding roots declined with increasing density, and a tapering tendency was seen in structure of the roots. The interaction of data logically suggests that nitrogen significantly affect root volume in high dose. As the healthy plant tends to keep its roots and shoots in a specific proportion (balance). The increase in plant density on the other hand reduce the volume of soil available for roots to grow, as we reduce row-row spacing the competition renders the root zone compacted and depleted limiting plant growth hence roots growth. Considering the interaction, the roots restriction soil (low nitrogen) renders the plant to be weaker. While where nitrogen is high and density is also high the plant roots extend to the soil in search of nutrients and water, thus resulting in the tapering of primary and secondary roots and reduction in number of feeding roots.

According to [8] who examined the xylem segregation in new roots of varying root diameters in three year old peach, Prunus persica (L.) trees supplied with different amounts of nitrogen. Primary xylem segregation, as the number of xylem ridges in cross sections of new, roots increased significantly with increasing root diameters, irrespective of varying amounts of nitrogen. The number of xylem ridges ranged from three to seven in peach roots. These results indicated that the numbers of thick roots having many primary xylem cells increased more in nitrogen fertilized plants than in those receiving no nitrogen. [9] also found that the soil volume reduction and the planting density increase both negatively 
affected the root growth: the root system

spreading was repressed.

Table 5. Effect of different nitrogen doses and plant densities on root volume $\left(\mathrm{cm}^{3}\right)$ of peach seedling

\begin{tabular}{|c|c|c|c|c|}
\hline \multirow{2}{*}{$\begin{array}{l}\text { Plant density } \\
\text { (No. of plants per } 31.60 \mathrm{~m}^{2} \text { ) }\end{array}$} & \multicolumn{3}{|c|}{ Nitrogen Levels $\left(\mathrm{kg} \mathrm{ha}^{-1}\right)$} & \multirow[t]{2}{*}{ Mean } \\
\hline & $\overline{\mathbf{0}}$ & 57 & 114 & \\
\hline 536 & 480 de & $753 \mathrm{a}$ & $783 \mathrm{a}$ & $672 \mathrm{a}$ \\
\hline 804 & 448 ef & $576 \mathrm{bc}$ & 746 a & $590 \mathrm{~b}$ \\
\hline 1005 & 436 ef & $505 \mathrm{~d}$ & $611 \mathrm{~b}$ & $517 \mathrm{c}$ \\
\hline 1072 & $418 \mathrm{f}$ & $476 \mathrm{de}$ & $526 \mathrm{~cd}$ & $473 \mathrm{~d}$ \\
\hline Mean & $445 \mathrm{c}$ & $577 \mathrm{~b}$ & $667 \mathrm{a}$ & \\
\hline
\end{tabular}

LSD for Nitrogen $=43.80$, LSD for Plant density $=31.14$, LSD for $\mathrm{N} \times \mathrm{R}=53.93$

\section{Conclusion and recommendations}

The conclusions of the research work are summarized that nitrogen at the rate of 114 $\mathrm{kg} \mathrm{ha}{ }^{-1}$ performed better as compared to other nitrogen treatments. The plots receiving $114 \mathrm{~kg}$ nitrogen ha ${ }^{-1}$ with 804 plants (12 rows plots $\left.{ }^{-1}\right)$ was recorded best performing plots as the number of healthy plants is maximum as compared to other high density plots. Although the competition was moderately high in plots with 804 plants (12 row plots $\left.{ }^{-1}\right)$, but the plants thus hardened are expected to perform better in field. Nitrogen dose of $114 \mathrm{~kg} \mathrm{ha}^{-1}$ is the best for peach nursery. The plots having 804 plants (12 rows plot $^{-1}$ ) is recommended for peach nursery, in order to get more plants per unit area. Double row pattern is a tool for increasing the number of plants per unit area, thus intensifying the nursery business. Further research must be carried out using innovative patterns to increase number of plants per unit area.

\section{Authors' contributions}

Conceived and designed the experiments: $S$ Jamal, Performed the Experiments: JA Shah, J Ali, M Ismaeel, Z Bacha \& A Khan, Analyzed the Data: I Naeem, Contributed reagents/ materials/ analysis tools: J Ali, Wrote the paper: JA Shah.

\section{References}

1. Sun X, Lou N, Longhurt B \& Lou J (2008). Fertilizer Nitrogen and Factor effecting Pasture Responces. The Open Agriculture Journal 2: 35-42

2. Akram N, Aziz MA \& Mohar TA (2004). Effect of planting distance on tree growth and fruit quality of shamber grape fruit under agro climatic conditions of sargodha. ISHS Acta Horticulturae 282: I International Symposium on Kiwifruit

3. Haq I, Hussain TA \& Ali N (1985). Influence of nitrogen on bud take and growth of apple nursery plants. Sarhed J of Agric 1(2): 43-35.

4. Rahman R, Rafiq M, Nabi G \& Abdul Samad (2007). Effect of Soil Media on Peach seed Germination and Seedling Growth in Climatic Condition of Orakzai Agency. Sarhad J Agric Vol. 23: No. 3.

5. Simões MP, Luz JP, St. Aubyn A, Mexia A \& Calouro MF (2010). Effect of Nitrogen Levels and Climate Factors on Susceptibility of Peach Trees to Phomopsis Amygdale. Acta Hort (ISHS) 868:451-456

6. Rieger M \& Myers SC (2002). Growth and yield of high density peach trees as influenced by spacing and rooting volume. ISHS Acta Horticulturae 451: 476

7. Wazir FAK (1987). Effect of different levels of nitrogen on seedling vigour, bud take success and plant vigour on 
peach "Peshawar local" root stock, Record 284, Fertilizing and Fertilizers.

8. Rufati J \& Dejong T (2001). Estimating seasonal nitrogen dynamics in peach trees in response to nitrogen availability. Tree Physiology 21: 11331140.
9. Pan CX, Cui S \& Nii N (2005). Effect of nitrogen fertilization on primary xylem differentiation in roots of young peach [Prunus persica] trees. Journal of the Japanese Society for Horticultural Science 74(5): 392-394. 